\title{
INVESTIGATION OF QUANTITY AND CHEMICAL CHARACTERISTICS OF BIGHEAD CARP (Aristichthys nobilis) BY-PRODUCTS
}

Đorđe Okanovićc ${ }^{\star}$, Milutin Ristić ${ }^{1}, \breve{S}$ andor Kormanjoš ${ }^{1}$, Tatjana

Tasić ${ }^{1}$, Predrag Ikonić ${ }^{1}$, Šojić Branislav ${ }^{2}$, Miloš Pelić ${ }^{3}$

${ }^{1}$ University of Novi Sad, Institute of Food Technology, Novi Sad, Republic of Serbia

${ }^{2}$ University of Novi Sad, Faculty of Technology, Novi Sad, Republic of Serbia

${ }^{3}$ Scientific Veterinary Institute "Novi Sad”, Novi Sad, Republic of Serbia

\section{Abstract}

Bighead carp (Aristichthys nobilis) successfully grow in polyculture with carp, feeding on plankton. It has good quality of meat for both consumption and industrial processing. The quantity of by-products obtained during primary processing of bighead carp and chemical characteristics of internal organs were investigated in this paper. The total average weight of by-products was $760.45 \mathrm{~g}(42.31 \%)$ in relation to live body weight, which was cca $1797.5 \mathrm{~g}$. The by-product contributing to the largest quantity to total live body weight was the head with $529.39 \mathrm{~g}$ ( $29.45 \%$ of live body weight), followed by complete internal organs and tail and fins, which weighed $137.67 \mathrm{~g}(7.66 \%)$ and $68.82 \mathrm{~g}(3.83 \%)$, respectively Chemical composition of internal organs of bighead carp was mostly water (60.99\%), following by crude fats and crude proteins $(21.20 \%$ and $10.61 \%$, respectively). The low collagen content (15.25\% of total crude protein) indicates the high nutritional quality of protein content from internal organs. Nitrogenous complexes from the internal organs were predominantly proteins. Digestible nitrogen was approximately equal to total nitrogen (92.04\%), indicating that all proteins of the internal organs had high biological value. Based on the results obtained, it can be concluded that bighead carp internal organs could be important sources of proteins and fats, and thus, could be used in Serbia as a raw material for feed and technical fat production.

Key words: bighead carp by-products, quantity, chemical characteristics

${ }^{1 *}$ Corresponding author: djordje.okanovic@fins.uns.ac.rs 


\title{
ISPITIVANJE KOLIČINA I HEMIJSKIH KARAKTERISTIKA SPOREDNIH PROIZVODA TOLSTOLOBIKA (Aristichthys nobilis)
}

\author{
Đorđe Okanović ${ }^{1}$, Milutin Ristić ${ }^{1}$, Šandor Kormanjoš ${ }^{1}$, Tatjana \\ Tasić ${ }^{1}$, Predrag Ikonić ${ }^{1}$, Šojić Branislav ${ }^{2}$, Miloš Pelić $^{3}$ \\ ${ }^{1}$ Univerzitet u Novom Sadu, Institut za prehrambene tehnologije, Novi Sad \\ ${ }^{2}$ Univerzitet u Novom Sadu, Tehnološki fakultet, Novi Sad \\ ${ }^{3}$ Naučni institut za veterinarstvo "Novi Sad", Novi Sad
}

\section{Kratak sadržaj}

Sivi tolstolobik (Aristichthis nigra) uspešno raste u polikulturi sa šaranom, hrani se planktonima. Meso ove ribe je izvrsnog kvaliteta i veoma pogodno za industrijsku preradu. U ovom radu ispitivana je količina sporednih proizvoda dobijenih tokom klanja i primarne obrade sivog tolstolobika i hemijske karakteristike unutrašnjih organa. Prosečna ukupna masa sporednih proizvoda bila 760,45 g ili 42,31\% u odnosu na masu žive ribe, 1797.5 g. Najveću masu imale su glave 529,39 g ili 29,45\% u odnosu na masu žive ribe, slede unutrašnji organi $(137,67$ g or $7,66 \%)$ i masa repa i peraja $(68,82$ g or $3,83 \%)$. Hemijski sastav unutrašnjih organa sivog tolstolobika u osnovi sastoji se uglavnom od vode (60.99\%), nakon čega sledi udeo sirovih masti $(21,20 \%)$ i sirovih proteina $10,61 \%$. Nizak sadržaj kolagena $(15,25 \%)$ u ukupnim sirovim proteinima ukazuje na visoku hranljivu vrednost proteina unutrašnjih organa. Azotni kompleks ispitivane sirovine pretežno se sastoji od proteina. Svarljivost azota je približno jednaka sa ukupnim azotom (92,04\%), što ukazuje da proteini unutrašnjih organa imaju visoku biološku vrednost. Na osnovu dobijenih rezultata može se zaključiti da unutrašnji organi sivog tolstolobika predstavljaju značajan izvor proteina i masnih kiselina, i tako se mogu koristiti kao sirovina za proizvodnju hrane za životinje i tehničke masti.

Ključne reči: sivi tolstolobik, sporedni proizvodi, hemijske karakteristike 


\section{INTRODUCTION}

The aquaculture industry has grown rapidly over the last decade. Likewise, mariculture is expanding worldwide thereby increasing the demand for feed ingredients to support production (FAO, 2014). The rapidly growing sector directly depends on the aquafeed industry, which in turn largely depends on fish meal as its primary protein source.

Over the last decade, the global supply of fish meal has been limited, and meeting the demands of a growing industry has become challenging. In addition, fish meal proteins experience periodic fluctuations in pricing and availability (Tacon et al., 2008).

Freshwater fish contain high levels of PUFA, which makes them very important in human nutrition (Vladau et al., 2008). Since there are a number of biochemical interactions between the n- 6 and $n-3$ series fatty acid, a balanced ratio between these fatty acids in the food is important for the normal functioning of the body in humans, as well as in animals (Đorđević et al., 2009). Consumption of fish meat is increasing, due to its high content of polyunsaturated fatty acids (PUFA), amino acids and lipid soluble vitamins which are important ingredients for human health. According to the latest data from FAO (Ćirković et al., 2012) the Republic of Serbia is a country where the average consumption of fish is $5-10 \mathrm{~kg}$ per capita per year, which is significantly below the European and global consumption (Ćirković et al., 2011).

Common carp is economically the most significant farmed fish species on the fish farms in Serbia (FAO, 2012), and the cyprinids are the most common species in the total world production of freshwater fishes (71.9\%, 24.2 million tons in 2010) (Ćirković et al., 2012). Bighead carp (as well as grass carp) was imported in our country as a regulator of hydro vegetation. It feeds on higher underwater plants and its meat is of good quality (Vujković et al., 1993).

Manufacturing and development of fish products could increase the offer and contribute to better sale of fish, not only in traditional fish markets, but also in retail stores and supermarkets. Technological processes, preservation and storage of fish meat differ from those characteristic for mammalian meat (Okanović et al., 2015). For proper manufacturing of fish products, knowledge about chemical composition and characteristics of raw fish meat is of highest importance in order to apply the most appropriate technology procedures adjusted to individual fish species.

Fish processing and development of new fish products can provide novel sale of fish, not only in traditional fish markets, but also in all other consumer goods stores (Baltić et al., 2009). The demands of modern markets are increas- 
ingly directed towards processed fish, especially fillets. Larger quantities of edible and non-edible by-products are obtained in industrial conditions of primary fish processing (Ristić et al., 2002).

Fish yield, expressed as the ratio of the weight of the carcass without the head, scales, fins and internal organs and whole fish mass, are essential parameters for all technological operations related to fish processing, since the economy of production is directly dependent on it (Ljubojević et al., 2012).

On the basis of some previous research, it is well-established that byproducts of bighead carp processing contain valuable nutrients, which may be sources for the food, pharmaceutical and feed industry (Ristić et al., 1992). In order to obtain more complete perception of the quality of animal by-product, it is necessary, in addition to knowledge of basic chemical composition, to obtain complete information on the quality of the most important nutritional components - proteins. However, the high crude protein content of some raw materials does not guarantee its high usability, ie. protein digestibility (Ristić et al., 2011).

Inedible by-products obtained during bighead carp slaughter belonging to the third category of by-products (Regulation EC, 2009) are important sources of proteins and fats that represent convenient raw materials for processing into proteinaceous feeds for swine and pets.

Due to the increasing industrial grass carp processing and need for complex utilization of obtained by-products, the aim of this research was to investigate the quantity of by-products and nutritive value of internal organs.

\section{MATERIALS AND METHODS}

The quantity of by-products and quality of internal organs were monitored during fish harvesting and processing of bighead carp from fish ponds in Vojvodina in industrial conditions.

Bighead carp from fish ponds Ečka were delivered live from fish farm to a manufacturing plant where they were immediately sacrificed. Mean values of bighead carp mass were approximately $1800 \mathrm{~g}$. Scales, gills and viscera, heads (flat transverse incision just behind the gill arch) and the fins were removed with a knife (Photograph 1). The following values were measured: weight of fish before the cutting, meat head, mass of the tail and fins and mass of total internal organs. The total internal organs are not separated because in industrial conditions it is standard procedure. 

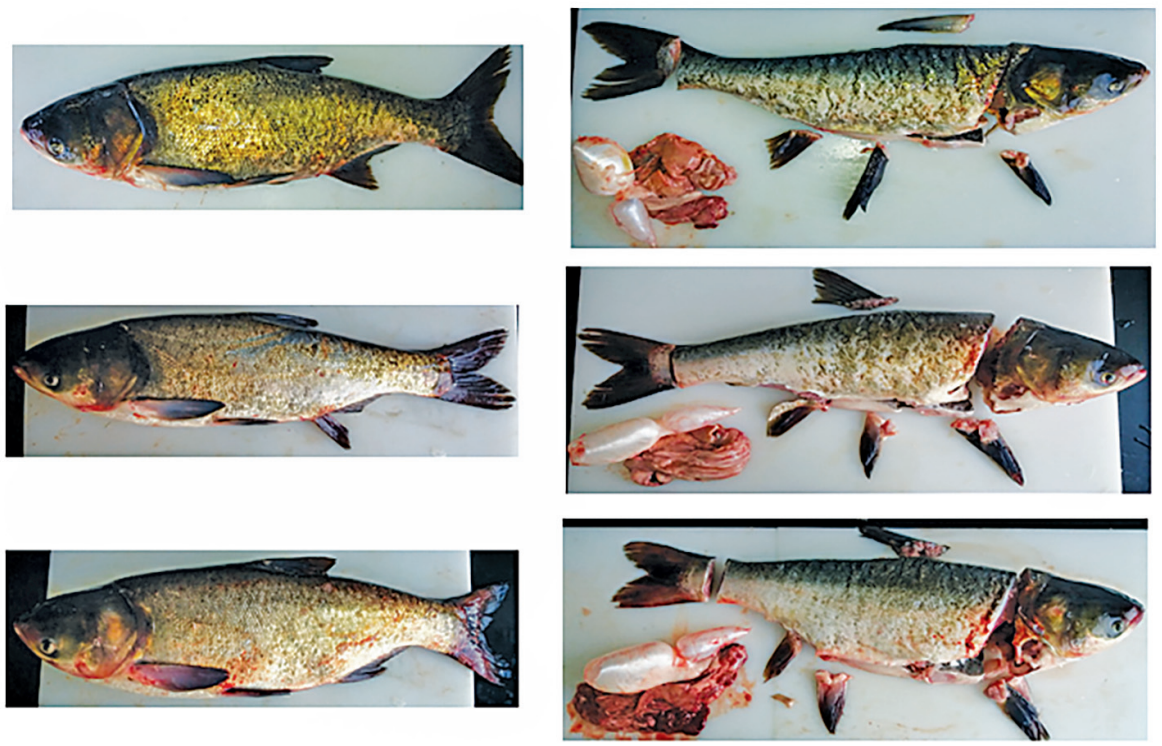

Figure 1. Cuting of bighead carp

Investigation of chemical characteristics of internal organs were performed in the laboratory of the Institute of Food Technology in Novi Sad. Slaughtered bighead carp, according to the structure of the by-products, were used as one sample (was one set of internal organs from one fish) for further investigations. The samples composed in such a way were put in plastic bags, labeled and regrigerated at about $4^{\circ} \mathrm{C}$. Four hours after the slaughter, samples were transferred into the chemical laboratory. All samples were ground with a homogenizer prior to examination and used for determining the chemical parameters. The samples were packed into aluminium foil bags and stored for $24 \mathrm{~h}$ at $+4^{\circ} \mathrm{C}$.

The basic chemical composition was assessed by determining moisture content (SRPS ISO 1442, 1997), total protein content (SRPS ISO 937, 1992), hydroxyproline content - the relative content of connective tissue proteins content (SRPS ISO 3496, 2002), free fat content (SRPS ISO 1444, 1997), and total ash content (SRPS ISO 936, 1998). Nitrogen fractions and digestible nitrogen were determined according the AOAC methods for free fat content (AOAC, 1998).

To the purpose of appropriate interpretation of the obtained data they were statistically evaluated (Stat Office RS, 2014) using calculations of arithmetic mean $(\bar{X})$, standard deviation (SD) and coefficient of variation $(\mathrm{CV})$. 


\section{RESULTS AND DISCUSSION}

The quantities of by-products obtained from bighead carp processing are presented in Table 1. After cutting-off the head, tail and fins and removal of complete internal organs, average carcass weight was $1013.55 \mathrm{~g}(56.39 \%)$ of total live body weight. Routine removal of skin, bones, spinal and rib carcass produced an average fillet weight of $817.29 \mathrm{~g}(45.47 \%)$ and the bones with the remains of the corresponding meat. Total average weight of by-products was $760.45 \mathrm{~g}(42.31 \%)$ in relation to livebody weight which was cca $1797.5 \mathrm{~g}$. The by-product with the largest proportion of total live body weight was the head with $529.39 \mathrm{~g}(29.45 \%)$, followed by the whole internal organs and the tails and fins which had weight $137.67 \mathrm{~g}(7.66 \%)$ and $68.82 \mathrm{~g}(3.83 \%)$, respectively.

The head weight largely depends on the processing method (straight or round cut behind the gills). In the research of Tumbas and Petrović (1978), the head obtained with a circular cut was $11 \%$ of the live body weight. The weight of tail and fins $99.15 \mathrm{~g}$ (5.11\%) was smaller than the weight of heads. Total internal organs weighed $143.77 \mathrm{~g}$ (12.22\%). According to Ristić et al. (1992) bighead carp by-products percentages ranged from head $19.79 \%$, tail and fins $3.09 \%$ and total internal organs $9.47 \%$.

Table 1. Quantity of bighead carp by-product, $g$ and \%*

\begin{tabular}{lcccc}
\hline & $\bar{X}$ & SD & CV & $\%$ \\
\hline & $\mathbf{1 7 9 7 . 5 0}$ & $\mathbf{9 8 . 2 3}$ & $\mathbf{5 . 4 6}$ & $\mathbf{1 0 0 . 0 0}$ \\
\hline Scales & 24.57 & 2.49 & 10.13 & 1.37 \\
Head & 529.39 & 31.65 & 5.98 & 29.45 \\
Tail and fins & 68.82 & 5.11 & 7.43 & 3.83 \\
Total internal organs & 137.67 & 12.22 & 8.88 & 7.66 \\
\hline Total by-products & $\mathbf{7 6 0 . 4 5}$ & $\mathbf{5 1 . 3 2}$ & $\mathbf{6 . 7 5}$ & $\mathbf{4 2 . 3 1}$ \\
\hline Fillet & 817.29 & 75.33 & 9.22 & 45.47 \\
Bones and skin & 196.26 & 19.56 & 9.97 & 10.92 \\
\hline Carcass & $\mathbf{1 0 1 3 . 5 5}$ & $\mathbf{8 3 . 1 4}$ & $\mathbf{8 . 2 0}$ & $\mathbf{5 6 . 3 9}$ \\
\hline
\end{tabular}

${ }^{\%} \%$ according to bighead carp live weight

Results of the chemical composition of the internal organs are shown in Table 2.

Basic chemical composition showed that this raw material, apart from 
water (60.99\%), contained mostly crude fat $(21.20 \%)$ and then crude proteins (10.61\%). The low proportion of collagen (15.25\%) in the total crude protein indicates the high nutritional quality of the protein.

In the research of Ljubojević et al. (2013), the fat content in the bighead carp ranged from 2.3 to $16.8 \%$, while the protein content was less variable and generally was in the range from 14 to $18 \%$

Table 2. Chemical composition of bighead carp internal organs, $\%$

\begin{tabular}{lccc}
\hline Parameter & $\overline{\mathrm{X}}$ & $\mathrm{SD}$ & $\mathrm{CV}$ \\
Moisture & 60.99 & 4.53 & 7.43 \\
Crude protein & 10.61 & 0.96 & 9.06 \\
Relative content of con- & & & \\
nective tissue proteins & 15.25 & 1.21 & 7.93 \\
Crude fat & 21.20 & 2.35 & 11.08 \\
Ash & 0.85 & 0.06 & 6.85 \\
\hline N-free extract & 6.35 & 2.43 & 38.19 \\
\hline Non-protein N & 0.79 & 0.11 & 24.70 \\
\hline Protein digestibility & 92.04 & 0.92 & 1.00 \\
\hline
\end{tabular}

As seen in Table 2, nitrogen complex of bighead carp internal organs was composed mostly of protein. The high digestibility of the protein $(92.04 \%)$ indicates the high biological value of proteins of the internal organs. In the research of Ristić et al. (2002) it has been shown that a set of internal organs of bighead carp contained a higher share of fat $(21.20 \%)$ as well as protein with good digestibility (92.04\%).

\section{CONCLUSIONS}

Based on the results obtained in this study it is possible to conclude the following:

- After cutting-off the head, tail and fins and removal of complete internal organs the average carcass weight was $1013.55 \mathrm{~g}$ (56.39\%) of the live weight.

- The total average weight of by-products was $760.45 \mathrm{~g}$ or $42.31 \%$ in relation to live body weight (cca $1797.5 \mathrm{~g}$ ).

- The head had the largest proportion of weight in relation to live weight, being $529.39 \mathrm{~g}(29.45 \%)$ of live weight. Weights of tail and fins were much smaller, 
being $68.82 \mathrm{~g}$ (3.83\%). The total internal organs weighed $137.67 \mathrm{~g}(7.66 \%)$.

- Chemical analyses revealed that the internal organs, apart from water, contained significant amounts of crude fat $(21.20 \%)$ and protein (10.61) making them suitable for feed processing.

- The amount of digestible nitrogen in the internal organs was approximately equal to total nitrogen $(92.04 \%)$, indicating that all proteins from the internal organs have high biological value.

- Inedible internal organs obtained during bighead carp slaughtering could be an important source of nutritive components and could be used as raw material for processing into feeds for use in animal nutrition.

\section{ACKNOWLEDGEMENTS}

Investigations were carried out within the project "The quantity, quality and the possibility utilization of by-products origin from the growing and processing of fish from the fish pond on the territory AP Vojvodina" financially supported by the Municipality secretary of science and technological development, No. 114-451-480/2016 and the project "The influence of the quality of the food components for cyprinid fish species on the quality of meat, losses and the profitability of production", No. TR 31011, financed by Ministry of Education, Science and Technological Development, Republic of Serbia.

\section{REFERENCES}

1. AOAC: Official methods of analysis (16th ed.). Gaithersburg, MD: Association of Official Analytical Chemists, 1998.

2. Baltić M., Kilibarda N., Dimitrijević M.: Factors significant for the shelflife of fish and selected fish products in retail. Tehnologija mesa, 50, 1-2, 166-176, 2009.

3. Ćirković M., Ljubojević D., Đorđević V., Novakov N., Petronijević R., Matekalo-Sverak V., Trbović D.: The Breed Effect on Productivity and Meat Nutrient Compsition of Fish. Kafkas Üniversitesi Veteriner Fakültesi Dergisi, 18, 5, 775-780, 2012.

4. Ćirković M., Trbović D., Ljubojević D.: Meat quality of fish farmed in polyculture in carp ponds in Republic of Serbia. Tehnologija mesa, 52, 106121, 2011.

5. Đorđević V., Baltić M., Ćirković M., Kilibarda N., Glamočlija N., Stefanović S., Miščević M.: Quantitative and qualitative determination of enrofloxacin residues in fish tissues. Acta Veterinaria Belgrade, 59, 5-6, 579-589, 2009. 
6. FAO: Demand and supply of aquafeed and feed ingredients for farmed fish and crustaceans: trends and future prospects. In: The State of World Fisheries and Aquaculture, 172-181, 2012.

7. FAO: The State of World Fisheries and Aquaculture 2014. Rome, str. 223, 2014. http://www.fao.org/3/a-i3720e.pdf

8. Ljubojević D., Ćirković M., Novakov N., Babić J., Lujić J., Marković T.: Faktori koji utiču na randman šaranskih riba, Tehnologija mesa, 53, 1, 14-19, 2012.

9. Ljubojević D., Ćirković M., Đorđević V., Puvača N., Trbović D., Vukadinov J., Plavša N.: Fat quality of marketable fresh water fish species in the Republic of Serbia. Czech Journal of food sciences, 31, 445-450, 2013.

10. Okanović Đ.: Randman ciprinidnih vrsta riba. In: Ćirković M., Ljubojević D., Novakov N., Đorđević V.: Gajenje i kvalitet mesa šaranskih riba", Novi Sad, Naučni institut za veterinarstvo "Novi Sad", 2015, str. 256-266.

11. Regulation EC. Laying down health rules as regards animal by-products and derived products not intended for human consumption and repealing Regulation (EC) No 1774/2002 (Animal by-products Regulation). Regulation (EC) no 1069/2009 of the European Parliament and of the Council of 21 October 2009. Official Journal of the European Union, L300/1, 2009.

12. Ristić M., Kormanjoš Š., Milić M., Ćurčić R., Petrović, N.: Utvrđivanje količina i kvaliteta sporednih proizvoda koji se dobijaju preradom slatkovodnih riba. Tehnologija mesa, Beograd, 32, 3, 87-92, 1992.

13. Ristić M., Filipović S., Sakač M.: Liquid protein feedstuff from freshwater fish by-products as a component of animal feed, Roumanian Biotechnological Letters, Bucharest, 7, 3, 729-736, 2002.

14. Ristić M., Okanović Đ., Sakač M.: Karakteristike životinjskih sporednih proizvoda i njihova namena, Monografija, FINS Novi Sad, str. 195, 2011.

15. SRPS ISO 1442:1997. Meat and meat products - Determination of the moisture content.

16. SRPS ISO 937:1992. Meat and meat products - Determination total protein content.

17. SRPS ISO 3496:2002, Meat and meat products - Determination hydroxyproline content - the relative content of connective tissue proteins.

18. SRPS ISO 1444:1997. Meat and meat products - Determination of free fat content.

19. SRPS ISO 936:1998. Meat and meat products - Determination total ash content.

20. Statistical Office of the Republic of Serbia 2014: http://webrzs.stat.gov.rs/ WebSite/ 
21. Tacon A.G.J., Metian M.: Global overview on the use of fish meal and fish oil in industrially compounded aquafeeds: trends and future prospects. Aquaculture, 285, 146-158, 2008.

22. Tumbas Lj., Petrović M.: Uticaj težine tolstolobika na randman mesa, $R i$ barstvo Jugoslavije, 5, 116, 1978.

23. Vladau V., Bud I., Stefan R.: Nutritive value of fish meat comparative to some animals meat. Bulletin of University of Agricultural Sciences and Veterinary Medicine. Animal Sciences and Biotechnologies, 65, 1-2, 301-305, 2008.

24. Vujković G., Jovanović B., Marošan Lj., Manojlović D., Svrzić G.: Sporedni proizvodi slatkovodnih riba - potencijalna sirovina za stočnu hranu. Tehnologija mesa, 34, 2-3, 99-100, 1993.

Primljeno: 13.10.2017.

Odobreno: 31.11.2017. 